\title{
A Non Invasive Technique to Detect Thyroid using Infrared Sensor
}

\author{
M. Malathi \\ Department of Electronics and \\ Communication Engineering \\ Kongu Engineering College \\ Perundurai-638560 \\ Tamil Nadu, India
}

\author{
P. Keerthigasri \\ Department of Electronics and \\ Communication Engineering \\ Kongu Engineering College \\ Perundurai-638560 \\ Tamil Nadu, India
}

\author{
S. Balambigai, $\mathrm{PhD}$ \\ Associate Professor \\ Department of Electronics and \\ Communication Engineering \\ Kongu Engineering College \\ Perundurai-638560 \\ Tamil Nadu, India
}

\begin{abstract}
Thyroid disease is a condition that affects the function of the thyroid gland. Generally there are four types of thyroid disease i) Hypothyroidism (low function) caused by not having enough thyroid hormones ii) Hyperthyroidism(high function) caused by having too much thyroid hormones iii) Structural abnormalities, such as enlargement of the thyroid gland iv) Tumours which can be benign or cancerous. The symptoms of hypothyroid include fatigue, low energy, weight gain, inability to tolerate the cold, slow heart rate, dry skin and constipation. The symptoms of hyperthyroid include irritability, weight loss, fast heartbeat, heat intolerance, diarrhoea, and enlargement of the thyroid. In both hypothyroidism and hyperthyroidism, there may be swelling of a part of the neck, which is also known as goitre.
\end{abstract}

The objective of this work is to develop a low cost smart sensing system to sense the human relative skin temperature through non-invasive method for detecting thyroid. It uses two different sensors, one for detecting the relative skin temperature variation and the other for measuring pulse rate of the subject. The microcontroller will process the variation detected by the sensors. A self-power non-contact thermopile sensor is used for detecting the relative skin temperature and a heart rate monitor is used for heart rate measurement. In this work an Arduino based heartbeat monitor is used which counts the number of heartbeats in a minute. Here a heartbeat sensor module is used which senses the heartbeat upon putting a finger on the sensor. This non invasive technique of thyroid detection gives an accuracy $83.33 \%$.

\section{General Terms}

Non invasive thyroid detection

\section{Keywords}

Relative skin temperature variation, Heart beat monitor.

\section{INTRODUCTION}

In thyroid detection, the radioactive method is used to detect the functioning of the thyroid gland. For example, thyroid diagnosis during pregnancy period causes radiation risk to the patient and affects the foetus also. Account to the clinically proven fact, a person with normal thyroid gland operation will cause a $65 \%$ energy absorption and $35 \%$ heat emission [12]. The classic symptom of poor thyroidism is being too cold and high thyroidism is being too hot based on the function of the thyroid gland. The thermal imaging is an example of the non invasive method. The noncontact thermal camera acquires the thermal coefficient value of the presenting object. Thermal imaging has been applied in many fields in medicine, to identify the gland area temperature coefficient [2], sport medicine [10], anaesthesiology [4], peripheral vascular diseases [1], Cancer diagnosis and breast diseases [11].

In this work a non invasive noncontact smart sensor is used for diagnosing thyroid. First part of this work is to detect the relative skin temperature. An IR (Infrared) thermopile sensor is used to detect the relative skin temperature variation. This sensor detects the thermal coefficient and the Arduino microcontroller helps to display the temperature value. The non contact thermopile sensor also detects the ambient and the skin temperature variation and it displays in both celsius and Fahrenheit scale.

In the second part of this work, the pulse rate sensor is used for detecting the pulse rate by putting a finger on the sensor for thyroid detection. An Arduino based heartbeat monitor is used which counts the number of heartbeats in a minute and the pulse rate is displayed.

\section{EXISTING METHODS}

\subsection{Blood Test}

Thyroid function tests are a series of invasive blood tests which is used to measure the working of thyroid. The available tests include the T3, T3RU, T4, and TSH. The technician will collect the blood in test tubes and send it to a laboratory for analysis. The T4, TSH test are the two most common thyroid function tests. The T4 test is the thyroxine test. A high level of T4 indicates an overactive thyroid (hyperthyroidism) [13].

\subsection{Laser Test}

Classification of thyroid sometimes uses laser based light absorption technique which is a non invasive one. Non invasive method of thyroid classification involves emission and reflectance of light. Most of this detection work is based on light absorption. Generally, emission of light involves reflection, absorbance and scattering on the surfaces. Observation of light absorbance by the receiver from the emitted light classifies the hypo \& hyperthyroidism.

The characteristics of the thyroid and its symptoms were important features of the skin surfaces which are highly evaluated and had been differentiated. needle was inserted into the thyroid nodule. The Laser treatment was performed through the needle and the amount of energy delivered was based on the size of the nodule. The patient was evaluated immediately after the procedure, one month after the procedure and again at 12 months [14].

\subsection{Ultrasonograhy Test}

Ultrasound is safe and painless and produces pictures of the interior body using sound waves. Ultrasound imaging is also called as ultrasound scanning or Sonography which involves the use of a small transducer (probe) and ultrasound 
gel placed directly on the skin. The high frequency sound waves are transmitted from the probe through the gel. Then the transducer collects the sounds that bounce back and a computer then uses those sound waves to create an image.Ultrasound examinations don't use ionizing radiation, thus there is no radiation exposure to the patient. Because ultrasound image is captured in real-time, it can show the structure and movement of the body's internal organs, as well as blood flowing through blood vessels[17].

\subsection{Thermography}

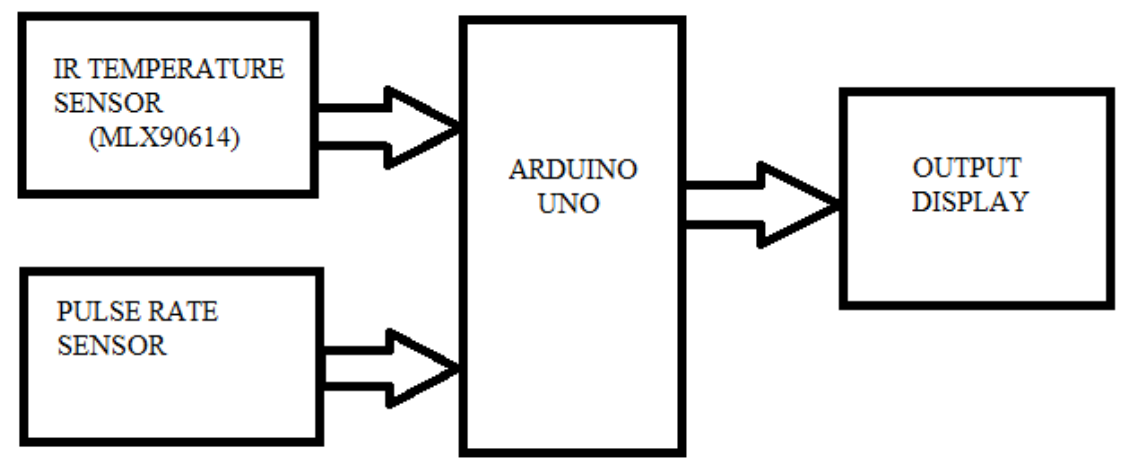

Figure 3.1 Block Diagram of the proposed non invasive thyroid detection

\subsection{Ir Temperature Sensor}

The IR temperature sensor is required for detecting the body temperature. The MLX90614 is an infrared thermometer sensor for noncontact temperature measurements. Both IR sensitive thermopile detector chip and signal conditioning ASSP(Application Specific and Standard Product) are integrated in the same TO-39 can. Due to its low noise amplifier, 17-bit ADC and powerful DSP unit, high accuracy and resolution of the thermometer is achieved. The thermometer comes factory calibrated with a digital PWM and SM Bus output. As a standard, the 10-bit PWM is configured to continuously transmit the measured temperature in range of -20 to $120{ }^{\circ} \mathrm{C}$ with the output resolution of $0.14{ }^{\circ} \mathrm{C}$ [15]. The MLX90614 is factory calibrated in wide temperature ranges: $40{ }^{\circ} \mathrm{C}$ to $125{ }^{\circ} \mathrm{C}$ for the ambient temperature and $-70^{\circ} \mathrm{C}$ to $382.2{ }^{\circ} \mathrm{C}$ for the object temperature. The 10-bit PWM is as a standard configured to transmit continuously the measured object temperature for an object temperature range of $-20^{\circ} \mathrm{C}$ to $120{ }^{\circ} \mathrm{C}$ with an output resolution of $0.14{ }^{\circ} \mathrm{C}$.

\subsubsection{Operating Principle}

The operation of MLX90614 is controlled by an internal state machine, which controls the measurements and calculations of the object and ambient temperatures and does the postprocessing of the temperatures to output them through the PWM output or the SM Bus compatible interface. The ASSP supports 2 IR sensors .The output of the IR sensors are amplified by a low noise low offset chopper amplifier with programmable gain, converted by a sigma delta modulator to a single bit stream and fed to a powerful DSP for further processing. To achieve the desired noise performance and refresh rate and for further reduction of the band width of the input signal, the signal is treated by a programmable FIR and IIR low pass filters[15].The measured result is the output of IIR(Infinite Impulse Response) filter and is available in the internal RAM(Random Access Memory). There are 3 different cells available, one for the on-board temperature sensor (on chip PTAT or PTC) and 2 for the IR sensors. Based on the above measured result, the corresponding ambient temperature and object temperature are calculated. Both
At first, medical infrared thermal imaging has been used to study the flow of blood to detect breast cancers and muscular performance of the human body[8]. Thermal image has been used to quantify sensitive changes in skin temperature in relation to certain diseases.

\section{METHODOLOGY}

The main objective of this work is to measure the body temperature and the pulse rate to detect the type of thyroid and to display the output. The block diagram is shown in Figure 3.1 .

calculated temperatures have a resolution of $0.01{ }^{\circ} \mathrm{C}$.

\subsection{Pulse Rate Sensor}

In medicine, the pulse represents the tactile arterial palpation of the heartbeat by trained fingertips. Resting heart (pulse) rate (RPR) is a potentially useful measure for neurological fitness. The normal RPR ranges for two different age groups are a) ages 6-15 (70-100 bpm) and b) 18 and over (60-100 bpm)[3]. The pulse can be noted in any place that allows an artery to be compressed near the surface of the body. It can be sensed at the neck, at the wrist, at the groin ,behind the knee, near the ankle joint, and on foot. Pulse measurement is equivalent to the heart rate measurement. It is a well-designed heart-rate sensor for arduino.

The sensor clips can be placed on a fingertip or earlobe and plugs into arduino. It combines a simple optical heart rate sensor with amplification and noise cancellation circuitry making it fast and to get reliable pulse readings easily. Also, it sips power with just $4 \mathrm{~mA}$ current draw at $5 \mathrm{~V}$.Simply clip the Pulse Sensor to your earlobe or finger tip and plug it into 3 or 5 Volt arduino [16] .

\subsubsection{Working of Pulse Rate Sensor}

The Pulse Sensor can be connected to Arduino, or plugged into a breadboard.The front of the sensor is the pretty side with the Heart logo that makes contact with the skin. At the front there is a small round hole and the LED shines through from the back, and there is also a little square just under the LED. The square is an ambient light sensor to adjust the screen brightness in different light conditions. The LED transmit light into the fingertip or earlobe, or other capillary tissue, and sensor receives the light that bounces back.

\section{RESULTS AND DISCUSSION}

For thyroid detection the normal body temperature is $97^{\circ} \mathrm{F}$ to $98^{\circ} \mathrm{F}$ (or) $36^{\circ} \mathrm{C}$ to $37^{\circ} \mathrm{C}$ [7]. The truth is that, at the extreme of thyroid function the thyroid cause changes in body function. During the hyperthyroid the body temperature is higher. The thyroid hormones play a major role in the metabolism of every cell of the body. It helps to increase the metabolism of 
more number of cells and helps to regulate the body's temperature levels. When thyroid hormone is dysregulated, body temperature will be altered.

\subsection{Basal Body Temperature (BBT)}

One of the important clinical symptoms of hypothyroidism is low body temperature. Analyzing the body's basal body temperature (BBT) through axillary (underarm) testing is an accurate way to assess your thyroid function in a low-cost, non-invasive way. This test was popularized by Dr Broda Barnes MD, which has been used by many medical and natural health care practitioners over the years[6].

While most people are aware that the standard body temperature is 98.6 degrees $\mathrm{F}$, the normal underarm temperature is $97.8-98.2$ degree $\mathrm{F}$ or $36.6-37$ degree C. If the temperature is consistently under 97.4 degree $\mathrm{F}$ or 36.5 degree $\mathrm{C}$, the subject must have under functioning thyroid activity. If the temperature is consistently above 100 degrees then the subject may have hyperactive thyroid activity[9].

\subsection{Normal Thyroid Function}

For thyroid detection the Normal Body Temperature: $97^{\circ} \mathrm{F}$ to $98^{\circ} \mathrm{F}$ (or) $36^{\circ} \mathrm{C}$ to $37^{\circ} \mathrm{C}$. The body temperature and the pulse rate was calculated for 12 normal subjects which is shown in the Table 1.

Table 1 Subjects with Normal Thyroid

\begin{tabular}{|c|c|c|c|c|c|c|}
\hline & Age & $\begin{array}{c}\text { Male } \\
\text { /Female }\end{array}$ & $\begin{array}{c}\text { Body } \\
\text { Temp } \\
\text { in }{ }^{\circ} \mathrm{C}\end{array}$ & $\begin{array}{c}\text { Body } \\
\text { Temp } \\
\text { in }{ }^{\circ}\end{array}$ & $\begin{array}{c}\text { Pulse } \\
\text { rate }\end{array}$ & $\begin{array}{c}\text { Doctor } \\
\text { confirm } \\
\text { ation }\end{array}$ \\
\hline $\begin{array}{c}\text { Subject } \\
1\end{array}$ & 20 & Female & 36.09 & 96.96 & 73 & Yes \\
\hline $\begin{array}{c}\text { Subject } \\
2\end{array}$ & 21 & Female & 36.47 & 97.65 & 91 & Yes \\
\hline $\begin{array}{c}\text { Subject } \\
3\end{array}$ & 36 & Male & 37.17 & 98.91 & 72 & Yes \\
\hline $\begin{array}{c}\text { Subject } \\
4\end{array}$ & 21 & Female & 36.23 & 97.21 & 94 & Yes \\
\hline $\begin{array}{c}\text { Subject } \\
5\end{array}$ & 41 & Male & 35.59 & 96.06 & 69 & Yes \\
\hline $\begin{array}{c}\text { Subject } \\
6\end{array}$ & 21 & Female & 36.15 & 97.07 & 89 & Yes \\
\hline $\begin{array}{c}\text { Subject } \\
7\end{array}$ & 27 & Female & 35.51 & 95.92 & 73 & Yes \\
\hline $\begin{array}{c}\text { Subject } \\
8\end{array}$ & 21 & Female & 36.57 & 97.83 & 96 & Yes \\
\hline & & & & & \\
\hline
\end{tabular}

\begin{tabular}{|c|c|c|c|c|c|c|}
\hline $\begin{array}{c}\text { Subject } \\
10\end{array}$ & 21 & Female & 36.79 & 98.22 & 92 & Yes \\
\hline $\begin{array}{c}\text { Subject } \\
11\end{array}$ & 39 & Male & 36.31 & 97.36 & 90 & Yes \\
\hline $\begin{array}{c}\text { Subject } \\
12\end{array}$ & 20 & Female & 36.29 & 97.32 & 95 & Yes \\
\hline
\end{tabular}

The age, gender and body temperature in both Celsius and Fahrenheit scale along with pulse rate is tabulated in table 1with doctor's confirmation. The temperature is a very good health monitor for non invasive thyroid detection[5]. Thus, it can be concluded that the above twelve subjects have normal thyroid function. The accuracy is 100 percentage.

\subsection{Hypothyroid Function}

For hypothyroid the body temperature is below $94.4{ }^{\circ} \mathrm{F}$ (or) $36.5{ }^{\circ} \mathrm{C}$ and the heart rate is typically 10 to 20 beats per minute slower than normal. The body temperature and the pulse rate was calculated for 4 Hypothyroid subjects which is shown in the Table.2.

Table 2 Subjects with Hypothyroid

\begin{tabular}{|c|c|c|c|c|c|c|}
\hline & Age & $\begin{array}{c}\text { Male } \\
\text { /Female }\end{array}$ & $\begin{array}{c}\text { Body } \\
\text { Temp } \\
\text { in }{ }^{\circ} \mathrm{C}\end{array}$ & $\begin{array}{c}\text { Body } \\
\text { Temp } \\
\text { in }{ }^{\circ}\end{array}$ & $\begin{array}{c}\text { Pulse } \\
\text { rate }\end{array}$ & $\begin{array}{c}\text { Doctor } \\
\text { confirm } \\
\text { ation }\end{array}$ \\
\hline $\begin{array}{c}\text { Subject } \\
1\end{array}$ & 42 & Male & 34.33 & 93.79 & 72 & Yes \\
\hline $\begin{array}{c}\text { Subject } \\
2\end{array}$ & 33 & Female & 34.09 & 93.93 & 69 & Yes \\
\hline $\begin{array}{c}\text { Subject } \\
3\end{array}$ & 54 & Female & 33.61 & 92.50 & 68 & Yes \\
& & & & & & \\
\hline $\begin{array}{c}\text { Subject } \\
4\end{array}$ & 30 & Female & 32.75 & 92.20 & 72 & $\begin{array}{c}\text { No } \\
\text { Inform } \\
\text {-ation }\end{array}$ \\
& & & & & & \\
& & & & & & \\
\end{tabular}


The age, gender and body temperature in both Celsius and Fahrenheit scale along with pulse rate is tabulated in table 2 with doctor's confirmation. It can be concluded that the above four subjects have hypothyroid function [5]. The accuracy is 75 percentage.

\subsection{Hyperthyroid Function}

For hyperthyroidism the Body Temperture is above $99^{\circ} \mathrm{F}$ (or) $37{ }^{\circ} \mathrm{C}$ and the heart rate is 10 to 20 beats higher than normal. The body temperature and the pulse rate was calculated for 4 hyperthyroid subjects which is shown in the Table 3.

Table 3: Subjects with Hyperthyroid

\begin{tabular}{|c|c|c|c|c|c|c|}
\hline & Age & $\begin{array}{c}\text { Male } \\
\text { /Femal } \\
\text { e }\end{array}$ & $\begin{array}{l}\text { Body } \\
\text { Temp } \\
\text { in }{ }^{\circ} \mathrm{C}\end{array}$ & $\begin{array}{r}\text { Body } \\
\text { Temp } \\
\text { in }{ }^{\circ} \mathrm{F}\end{array}$ & $\begin{array}{c}\text { Pulse } \\
\text { rate }\end{array}$ & $\begin{array}{l}\text { Doctor } \\
\text { confir } \\
\text { mation }\end{array}$ \\
\hline $\begin{array}{c}\text { Subject } \\
1\end{array}$ & 39 & Female & 38.25 & 100.8 & 75 & Yes \\
\hline $\begin{array}{c}\text { Subject } \\
2\end{array}$ & 51 & Male & 37.95 & 100.3 & 74 & Yes \\
\hline $\begin{array}{c}\text { Subject } \\
3\end{array}$ & 28 & Male & 37.29 & 99.12 & 75 & $\begin{array}{c}\text { No } \\
\text { Inform } \\
\text {-ation }\end{array}$ \\
\hline $\begin{array}{c}\text { Subject } \\
4\end{array}$ & 39 & Female & 37.61 & 99.70 & 77 & Yes \\
\hline
\end{tabular}

The age, gender and body temperature in both Celsius and Fahrenheit scale along with pulse rate is tabulated in table 3 with doctor's confirmation. It can be concluded that the above four subjects have hyperthyroid function[5]. The accuracy is 75 percentage.

\section{CONCLUSION}

The thyroid disease can be diagnosed by measuring body temperature and pulse rate. The cost of this method is low when compared to previous methods. The temperature and the pulse rate detection is an alternative diagnostic method to monitor the thyroid function. The proposed method has advantages of low cost, simple and non invasive. A low cost smart sensing system to sense the human relative skin temperature through non-contact and non-invasive method for detecting thyroid. This method can be used by the person to find whether one has any thyroid problem or not. This is one of the simple method for thyroid diagnosis. Developed method tests the medical data that is collected and gives the risk value of the individual. Twelve normal subject and eight abnormal subjects were tested. In case of abnormal subject all parameter range exceeds the normal range. So the subject is considered to be a patient with thyroid disease.The average accuracy of this method is $83.33 \%$.

This can be improved further when large data set is considered over a long period of time. The results of the proposed work confirm the thyroid problem, but it still needs to be tested in a real time environment to show its full clinical worth.

\section{REFERENCES}

[1] Aaueret J.J. (1991) " Hand skin blood in diabetic patients with autonomic neuropathy and microangiopathy', Diabetes Care Vol. 14 pp. 897-902.

[2] Ahdy Helmy, Michael Holdmann, and Maher Rizkalla. (2008) 'Application of Thermography for Non-Invasive Diagnosis of Thyroid Gland Disease', IEEE transactions on biomedical engineering Vol.55 No.3 pp. 0018-9294.

[3] John Hart (2015) 'Normal resting pulse rate ranges', Vol. 5 No. 8 pp.95.

Lawson. (1993) 'Infrared thermography in the detection and management of coronary artery disease', Amer. J.Cardiol., Vol. 72 pp. 896.

[4] Ahmad Ghafarpour and Iman Zare. (2016) 'A review of the dedicated studies to breast cancer diagnosis by thermal imaging in the fields of medical and artificial intelligence sciences', Biomedical Research., Vol. 27 No.2 pp. 543-552.

[5] https://drchristianson.com/basal-body-temperature-forthyroid-function-a-comprehensive-guide/.

[6] https://drjockers.com/test-thyroid-function.

[7] PallaviMahajan ,Swati Madhe . (2014) 'Morphological Feature Extraction of Thermal Images for Thyroid Detection' Vol. 5 NO.4 pp. 2249-071.

[8] Trinath Kumar Mishra, Prabeen Kumar Rath. (2011) ‘ Pivotal role of heart rate in health and disease' Vol. 12 NO.4 pp. 297-302.

[9] Bonnet P, Hare D.B, Jones C.D, Ring E.F.J and Hare C.J(2006), 'Preliminary observation on the effect of sports massage on the heart distribution of lower limb muscles during graded exercise tests, Thermography Int'., Vol.16 No.4 pp.143-149.

[10] Farrell C ,Mansfield C and Wallace $\mathrm{J}(1971)$,'Thermography as an aid in the diagnosis of tumours and detection of metastatic bone disease',Br.J.Radiol.,Vol.44 pp.897.

[11] B. Suresh Chander Kapali and S. Muttan (2017) ,'A Non-Invasive Technique to Detect Thyroid Dysfunction using Body Fluid and Temperature', JCHPS, Special Issue 11.

[12] https://www.healthline.com/health/thyroid-function-tests.

[13] https://www.thyroid.org/patient-thyroid-information/ctfor-patients/january-2016/vol-issue-10-11.

[14] www.alldatasheet.com/Mlx90614.

[15] https://wiki.eprolabs.com/index.php.

[16] https://www.healthline.com/health/thyroid-ultrasound 